\title{
The meaning of 'One' in Broome, Western Australia: From Yawuru tribe to Rubibi Corporation
}

\author{
Barbara Glowczewski
}

In recent years Broome, a coastal tourist town in northern Western Australia, has been regularly in the headlines for Aboriginal land issues while its population doubled from 6,000 to 12,000 . On Norman Tindale's map, Broome is located in the country of the Jugun tribe, north of the Yawuru tribe. ${ }^{1}$ Nowadays local people say that 'Jugun and Yawuru are one' and that Broome is in Jugun-Yawuru country. In fact Jugun language is also known as 'Big Yawuru'. ${ }^{2}$ The Yawuru Aboriginal Corporation which has been operating for over fifteen years originally included most Jugun families. Through different site surveys, protests and claims that have taken place in the name of Jugun and Yawuru country the patrilineal model of local affiliation proposed by early anthropologists $^{3}$ is now questioned as many people identify with the country inherited from their mother or in another way, through spiritual, ritual or marriage affiliation. The right to land of non Yawuru or non Jugun local people has also become an issue because several generations of indigenous people from other regions of Australia, including the Torres Strait Islands, have been settled in the town more or less forcibly through missions, orphanages and a rural exodus or been attracted by work. The advent of the Native Title Act 1993 (Cwlth) saw many local conflicts both between indigenous people themselves and with non indigenous people, but new alliances have built up an indigenous strategy concerning land management and town development, especially with the creation in 1994 of the Rubibi Working Group which is in the process of being incorporated as the Rubibi Aboriginal Land, Heritage and Development Council.

This paper discusses the way conflicts and alliances have evolved between the different local Aboriginal people and the role some women have played in this process aimed at an active Aboriginal participation in the development of Broome and a redefinition of the traditional language groups which have a right to this land. The different ways people identify with the country (through descent, spirit or the dreaming law ${ }^{4}$ ) and the evolution of Rubibi, the local Aboriginal representative body created to negoti-

1. In this text tribe is used in the way the authors quoted or the Aboriginal people refer to it.

2. McGregor 1988, p. 77

3. Elkin 1927-1928 (unpublished notes); Radcliffe-Brown 1930-1931, p. 341; Elkin 1933, pp. 26081 and $437-38$. 
ate development in Broome and reconcile different candidates for claims under the Native Title Act 1993 (Cwlth). It is important to stress that the process of bringing together all of the different claimants (Jugun, Yawuru and other locals) has evolved from an original tendency to homogenise and unite them under 'one voice' to the recognition of an inner dynamics where an even stronger differentiation into several groups is now encompassed by the current Rubibi representative body. Negotiations and mediations have outlined and strengthened differences between families which claim a specific identity by taking the geographic name of the place they identify with, such as the Goollarabooloo group, the Idar (Lake Eda) group, the Minyirr (Gantheaume Point) group or the Leregon 'clan', etc. Jugun, Yawuru and other Broome Aboriginal people are 'one' not as a homogeneous unit but more as a federation or a network of alliances between differentiated units, with some members having family in two or more units.

It is this process of unveiling identity diversification in the recent political structuring of the representative body that is the most interesting lesson of the 'Rubibi model'. It will be shown that the dynamics of identity reflects two influences. The first being the traditional process of local differentiation (based on country, language, rituals and kinship) which is reproduced through rules of exchange and secondly, the contemporary resistance to globalisation imposed by the Western lifestyle and bureaucratic and political structures. ${ }^{5}$

\section{Reconstructing the past}

Custody of land has been transmitted in the Broome region for over a century with and against the disruptive presence of settlers. Local Aboriginal owners have had to adapt to blackbirding and massacres in Roebuck Bay and other killings, imprisonment or forced labour on pearling boats and on stations and exile away from Broome. A lot of Asian indentured labour was brought by the pearling masters from Indonesia, Malaysia and the Philippines. Japanese divers and Chinese merchants gave birth to Broome's Chinatown. But the Aboriginal population was forbidden to mix with Asians. Different laws sent women to jail for prostitution when they dared live a married life with an Asian man. Children from European or Asian fathers were taken away and most grew up hundreds of kilometres away from Yawuru land, for instance at the Beagle Bay mission to the north or the Moore River mission to the south. But the attachment to the land of origin was strong and some two thousand Yawuru descendants still live in Broome, others being located in Darwin, the Pilbara, Perth and further away. They have learnt to share their land with Aboriginal neighbours who have come to town from bush communities on a permanent or temporary basis. One town reserve, Kennedy Hill is mostly inhabited by Bardi and Torres Strait Islander people the other by Karajarri, Nyikina,

4. Dreaming, widely used in Australia but rarely understood, is a dynamic concept encompassing different levels. Rather than a time of creation, it is a virtual space-time, where dreamers can communicate with eternal totemic ancestors and bring back new songs, designs and other collective memories. According to the context of speech and practice, dreaming refers to these eternal beings, the animals, plants or other phenomenas they embody as totems, the stories and song lines that tell of their journeys, the trails that materialise their presence on earth in the sacred sites, the power and the individual and collective identity embodied in their Aboriginal custodians. Glowczewski 1991, pp. 16-17 (Presses Universitaires de France). On 'law', see footnote 9 .

5. Glowczewski 1998a, p. 347 (Berg). 
Mangala and desert people. The majority of Yawuru people live in Homeswest houses in or outside of town. ${ }^{6}$

In 1987 a group of Yawuru women applied to a language funding body to initiate an oral history project. They wanted to find out from the Broome elders about traditional 'story places', what people were connected to them and the boundaries of the local languages. Having obtained a grant, they formed the Jarndu Yawuru Women's Group (Jarndu means woman in Yawuru) to record life stories and stories about country, some on tape and video. They found hundreds of toponyms corresponding to old camps or ceremonial grounds, special stones for increasing fish or turtle, dreaming tracks and song line sites on the coast, in the mangrove and offshore. In tracking down their places of origin, they discovered different genealogical links between the local families. They wanted to know if Broome country was Jugun or Yawuru because nobody seemed to really know. Most elders told them that Jugun and Yawuru are 'one' and share the custody of the land where the town was built. In 1991, I was asked to put this extremely rich data into a book form ${ }^{7}$ and also to expand the research more specifically into a systematic reconstitution of the local genealogies. Thanks to the fantastic memory of some of the women elders, twelve main branches of Jugun and Yawuru descendants including over 2,000 people were identified. These genealogies were to be used as a basis for the Kimberley Land Council to prepare local native title claims.

In 1994, the Jarndu Yawuru Women's Group had developed into an incorporated resource centre with 16 Community Development Employment Program employees training in silk screening and office work, offering creche facilities and a Yawuru language program. The women's group also continued to help organise political meetings involved with land issues. Some men were worried about the women being involved with land matters. But the women repeatedly assured them that they did not mean to touch any land business that was restricted to men. In the end women's initiatives, inside and outside the group, helped to promote the political actions of the men. In 1992, when some Aboriginal and non Aboriginal residents of Broome started to oppose the idea of a crocodile farm being built on the marsh at the entrance of the town, the Jarndu Yawuru Women's Group sent its objections to different authorities including, in particular the then state Minister for Aboriginal Affairs. A video message was produced in July with a Jugun Yawuru woman telling the story of the Two Snakes associated with the place. She explained that destroying such bugarri (dreaming) places is 'really hurting us' and that if the 'snake' that sits there is touched 'maybe Yawuru people will be wiped out'. But the minister did not oppose the proposed development and the shire agreed to lease a block of the town common for the crocodile farm. Both the minister and the shire legitimated their decision by using a letter from the former chairman of the Yawuru Aboriginal Corporation in which he did not object to the project. From the point of view of the Yawuru Aboriginal Corporation this man, who in the meantime had been asked to resign for other reasons, was not considered representative of the Yawuru community. In fact the Yawuru Aboriginal Corporation had invited

6. Jackson 1996, p.10 (North Australia Research Unit).

7. Glowczewski ed. 1994, 600 pages compilation of fifteen story-tellers with many archival photos, maps and genealogical boards and historical appendixes. 
the proponent of the crocodile farm to several meetings to inform him about their objections to his project but he never came.

\section{We still have 'law' in Broome}

In September 1992, the Yawuru Aboriginal Corporation with the support of other Aboriginal people living in town organised a protest camp on the contested site and a month later a large tent was set up there to host a meeting of the Aboriginal opponents with the shire. Aboriginal people in town had not shown their dissatisfaction and anger which such assertiveness since a young boy was killed by the bouncers of a hotel years before and the Noonkanbah dispute in $1980 .{ }^{8}$ The crocodile farm in this sense was a major event that strengthened in many local people the idea that they had a say about the future use of the country. People objected, asserting that Broome is not a crocodile country, that the feeding of the crocodiles $(1,000$ to be bred each year) would lead to the extinction of local fish, and that, if a crocodile escaped neither locals nor tourists would be safe. This last argument was supported by an environmental survey. But the main argument was cultural. The place was important for traditional activities, such as fishing and ceremonies.

The Kimberley Land Council, on behalf of the Yawuru people, made several applications for interlocutory junctions, both in the Supreme Court of Western Australia and in Federal Court of Australia, to prevent the issue of the lease. They were rejected. In the meantime the developer, a popular television personality, called for public support as his crocodiles were likely to die if they were not shifted urgently to this new site from his existing park in another part of town. His appeal was even broadcasted as a children's program. Five alternative sites were offered by the Yawuru Aboriginal Corporation, but in January 1994 the crocodile farmer was granted a lease over 21 hectares of the original block. The following month, the Yawuru sought temporary protection of this land from the Commonwealth Minister of Aboriginal and Torres Strait Islander Affairs under section 9 of the Aboriginal and Torres Strait islander Heritage Protection Act 1984 (Cwlth). The leased area was also included as part of the claim lodged by the Yawuru under the Native Title Act 1993 (Cwlth). The Commonwealth Minister for Aboriginal and Torres Strait Islander Affairs appointed as a mediator, Fred M. Chaney, a former minister, to investigate the situation and report to him on making a longer declaration before the protection provided under section 9 expired. The Jarndu Yawuru Women's Group offered its premises for the meetings.

Many elders from other parts in the Kimberley came to support the Yawuru people and to testify on the cultural importance of the site. The Kimberley Land Council appointed a lawyer and an anthropologist full-time to conduct the case and a report outlining eight aspects of cultural significance was submitted to Chaney. Chaney's report was examined by the minister who decided that the land would be protected by a declaration under section 10 for five years, a period after which the situation could be reconsidered if the local elders did not show continuing traditional and cultural usage of this place. The minister's decision relied on the particular cultural and sacred significance in accordance with Aboriginal tradition. After the Jarndu Yawuru Women's Group had stated that the place was associated with the very important Two Snakes

8. Hawke and Gallagher 1989, p. 317 (Fremantle Art Centre Press). 
dreaming, the male elders confirmed the secret level of that story and that touching the place was dangerous from a spiritual point of view. They also explained that the site was on the path to a ceremonial ground where initiation still took place.

Interestingly, the area of the dispute did not seem to have a public name, but was referred to as the Dampier Creek marsh or the path to the ground called Garnin on Fisherman Bend. It has to be noted that the Jarndu Yawuru Women's Group took an important role in reviving the use of this ground. They made all the material and financial arrangements so that Yawuru law could be performed again in Garnin after some ten years of inactivity. Thanks to their effort, in 1991, two Yawuru and two Karajarri young men were 'put through law' ${ }^{9}$ by Yawuru elders with the support of some Karajarri people of Bidyadanga (La Grange), and Nyikina and Mangala people of Looma (300 kilometres inland). For many years Yawuru boys and young men have been initiated by neighbouring tribes, in La Grange, Looma and Anna Plains. Some were initiated by Bardi people in One Arm Point or Djarindjin and Lombadina (Bardi settlements located some 200 kilometres north of Broome) or in the ceremonial ground the Bardi were given by Yawuru custodians to use for ritual purpose a few miles north-east from the entrance of the Broome town.

It can be noted that traditional support and participation of different tribes in the initiation of their respective boys seem to have always existed. ${ }^{10}$ Such exchange was legitimated not only by intertribal trade all across the Kimberley, through the well known Wunan system, but also through Dreaming trails shared across hundreds of kilometres by groups of very different languages and different environments of the coast, desert and river. The support given by the elders from the south coast (Karajarri), the north coast (Bardi) and inland (Nyikina, Mangala, etc.) confirmed the cultural significance of the Broome region and especially the Dampier Creek area where, apart from the Two Snakes, The Two Men song cycle, a 'law' shared by most Kimberley and Western desert people ${ }^{11}$ is significant.

9. 'Put through law' or 'going through law' in an Aboriginal understanding means being initiated. 'Law' refers to not only all the rules that constitute the rituals and other customs of Aboriginal society but also all the teachings and practices (such as dream interpretation, new songs and paintings) connected with the land and the dreamings.

10. Bates, Daisy no date (Early 1900s), Native vocabularies-Broome Magisterial District, typescript, Section 12, 2E:16; Social Organisation-genealogies, typescript, Section 3: $2 \mathrm{~L}, 2 \mathrm{M}, 2 \mathrm{~N}$; relationship terms, typescript, Section 3: 5J, I; Native names of places, Section /3E, notebooks $7 \mathrm{a}, 11 \mathrm{~b}$ (Canberra, National Library of Australia). ). Bates 1938, p. 22 (of 1966 reprint by Murray).Bates 1985, p. 163 (National Library of Australia).

11. The Yawuru film maker, Wayne Barker, has filmed the Balgo women's statement and dance related to this Two Men (Watikutjarra) law (Milli Milli, Australian Broadcasting Commission 1994). In an exhibition I organised in France in Grasse, Toulon and Paris with a catalog (Glowczewski 1991b with 30 painters from Balgo, Western Australia, and Lajamanu, Central Australia (where I have been working since 1979 with the Warlpiri people) some of the paintings were directly referring to the Two-Men dreaming (Glowczewski 1998b). The Two-Men law has been reported by many scholars, for instance, Tonkinson 1978, p. 110 (of 1991 reprint by Holt, Rinehardt and Winston). 


\section{Tribes, clans and corporations}

Tourists in Broome sometimes complain that they are not told much about local Aboriginal culture. While eating dinner at the Cable Beach Club they can have a feel of the old Broome and Beagle Bay mission atmosphere by listening to a cabaret version of the musical Bran Nue Dae written by the local composer Jimmy Chi who is of Bardi descent. If curious, they can take a walk along the coast following the Lurujarri Heritage Trail, from Broome up to Carnot Bay, with the Goollarabooloo organisation created by an Aboriginal man, author of a book also called Gularabulu, ${ }^{12}$ an expression used by the inland tribes to refer to the coastal tribes in Broome and to the south and north of the town. The author of the book is a Gularabulu man, not because of his mother who was an inland Nyikina or his father who was European, but because he grew up with the coastal people between La Grange and One Arm Point. His story to officials and academics like myself in $1980^{13}$ was that all the local Aboriginal custodians of the coastal country from Broome up to Carnot Bay (Jugun, Yawuru, Ngumbarl and Jabirr Jabirr) were extinct and he was given the custody of all this coastline before they died. ${ }^{14}$ According to him, the Jabirr Jabirr legacy was confirmed as his daughter incarnated a rayi spirit of Jabirr Jabirr country. She married a Yawuru man and their sons 'went through law ${ }^{\prime 15}$ in Broome. The family established the Goollarabooloo organisation to look after the country. Until the early 1980's they had a little museum to exhibit some local artefacts and with the help of the Western Australian Museum's Department of Sites they mapped the Lurujarri Trail over a hundred kilometres along the coast to protect sites of cultural and archaeological significance, and take visitors on guided tours. With the success of this trail, the Goollarabooloo members claimed to be the only custodians of the country encompassing the coastline of the Yawuru, Jugun, Ngumbarl, and Jabirr Jabirr tribes.

Early in the eighties, some Yawuru families got upset by this monopoly and created the Yawuru Aboriginal Corporation including Jugun families. ${ }^{16}$ A Karajarri elder, Tommy Edgar, living in Broome was given by his wife's Yawuru father, Tommy Roe, the Yawuru ritual boards and the custody of the local Aboriginal law he shared with a centenarian Yawuru elder, Paddy Djiagween. In 1968 they, together with other Yawuru elders, recorded Yawuru song cycles. ${ }^{17}$ It is during this process of Yawuru revival that the Yawuru Women's Group was set up to record oral history and to survey the places that were part of Yawuru land. One of the objectives was to discover the reality of the Jugun. Were they a different tribe or a clan of the Yawuru? Many Yawuru people, in their search for their family history received from the Aboriginal Affairs Planning

12. Roe 1983 (whole book).

13. Glowczewski 1983, p. 7

14. Ackerman 1994, p. 99, referring to the long 'regency' of this Aboriginal man reports that the Yawuru people have recently contested the extension of Jugun country to the whole of the town as is represented on Davis map (and Tindale's map). But Ackerman ignores the fact that Jabirr Jabirr families (which are not extinct) are also claiming their traditional rights to the country north of Broome.

15. See footnote 9 .

16. In the mid 1990 s some Jabirr Jabirr families also decided to create their own representative body and in the framework of the Native Title Tribunal they entered a process of mediation over the Jabirr Jabirr land claimed by Goollarabooloo.

17. Moyle 1981, p. 16. 
Authority (AAPA) in Perth or the Australian Institute of Aboriginal and Torres Strait Islander Studies (AIATSIS) in Canberra Norman Tindale's map that shows Broome in the country of the Jugun tribe and the Yawuru people as a separate tribe to the south of the town in the Roebuck Plain. But oral transmission was to the contrary. Most elders talked of Broome as Yawuru land, with Gantheaume Point being Jugun. For many locals Jugun was only designating a language variation of Yawuru.

At the turn of the century, the then Chief Protector of the North, Father Bishofs distinguished three 'tribes' referred to by their main place name: Gumbarn-nganyjal (Komberenial, Roebuck Plain) with a Yawuru (Yawor) language; Garnin (Karnen, Dampier Creek) with a Jugun (Tiogon) language and Minyirr (Menger, Gantheaume Point) with a Minyirr language. ${ }^{18}$ In the same period, Daisy Bates established a Jugun (Joogan) word list but talked of the Yawuru (Yowera, Yauera) people of Broome. ${ }^{19}$ Thirty years later, Father Worms did not differentiate the Jugun from the Yawuru but he distinguished three clans corresponding to the Bishofs' tribes (Minyirr in Gantheaume Point, Lirrigun or Leregon in Dampier Creek, Gumbarn-nganyjal in Roebuck Plain) plus a fourth clan to the south where the Thangoo Station was established (D'olbayi). He named other places but was not clear about their allocation between these four clans (his 1940 data differs from the 1944 data) and their connected totems. ${ }^{20}$ All Worms' localisations are confirmed by local families who identify their fathers or mothers with those places, except for the name D'olbayi which is not in use. People refer to this country and local group as Yardoogara or Thangoo Station mob. Nevertheless it has been suggested by some locals that D'olbayi is Dolby, the name of a Yawuru man from this southern region, ancestor of a large family. Local elders identify hundreds of toponyms not recorded by Worms. This oral knowledge combined with the way family heritage is connected with some places suggests that there was more than four local 'clans', for instance the inland Lake Eda and Yajugan groups, centred around two important ceremonial gathering places.

So were the Jugun and Yawuru one before? For the last fifteen years, linguists have defined Minyirr as a dialect of Jugun itself locally known as 'Big Yawuru' distinct from the 'Small Yawuru' spoken by the Yawuru to the south of Broome. ${ }^{21}$ In the 1980 s and early 1990's most families who considered themselves as Jugun also identified as Yawuru so they joined the Yawuru Aboriginal Corporation . It took a few years, discussions and conflicts before the Yawuru claims started to be recognised. It was only in 1992, when the Yawuru protested against the crocodile farm that the Western Australian Museum's Department of Aboriginal Sites, which through the registration of the sites of the Lurujarri Trail had acknowledged previously Goollarabooloo as the custodian for all these coastal sites, ${ }^{22}$ agreed to sit in meetings with the Yawuru Aboriginal Corporation and the Yawuru Women's Group to record what they had to say about the country.

18. Bishofs 1908, pp. 33-4.

19. Bates, Daisy no date (early 1900s), Native vocabularies-Broome Magisterial District, typescript, Section 12, 2E:16; Social Organisation-genealogies, typescript, Section 3: 2L, 2M, 2N; relationship terms, typescript, Section 3: 5J, I; Native names of places, Section /3E, notebooks 7a, 11b. (Canberra, National Library of Australia).

20. Worms 1940, pp. 213-282. Worms 1944, pp. 284-310.

21. McGregor 1988, p. 77; Hosokawa 1991, p. 5.

22. Bradshaw and Fry 1989, (whole report). 
Other surveys and claims were already being prepared on behalf of the Yawuru Aboriginal Corporation by the Kimberley Land Council.

Between 1992 and 1994 both the Western Australian Museum's Department of Aboriginal Sites and the Kimberley Land Council tried to organise a meeting of the Goollarabooloo organisation and the Yawuru Aboriginal Corporation with no success. $^{23}$ The situation was tense and bitter. Opposition masked personal alliances as many had relatives in both groups. At the same time a different split occurred. One Jugun woman claimed that Broome was not Yawuru but Jugun, a different tribe according to Tindale's map. Chaney had mentioned this problem in his report but concluded that the linguistic distinctions between Jugun, Yawuru and the complexity of the descent patterns of the local population were not relevant as all people with authority to speak on the cultural significance of the site of the crocodile farm dispute seemed to agree. So who were the people with authority to speak? According to Chaney's report, a few initiated older or younger men of Jugun or/and Yawuru descent through their mother or father, and represented by the Yawuru Aboriginal Corporation and Goollarabooloo. Some women elders were also granted this authority. ${ }^{24}$

\section{Rayi spirits, descent and land ownership}

The Native Title Act 1993 (Cwlth), people say locally, forces them to formalise a system of land ownership that was not thought about in those terms before. As they say: 'everybody knew which country they belong...' Many conflicts have opposed the two corporations claiming to be representative of the Broome local owners but other conflicts involve Aboriginal organisations set up in Broome to represent tribes whose members live between the town, their settlements or outstations to the North (Jabirr Jabirr, Nyul Nyul, Bardi). Consequently, the question of defining the criteria of what makes an Aboriginal owner in the Broome region has become central to many discussions. Does land ownership have to do with descent or with others factors? Elkin who was the only one to discuss the Yawuru social organisation, simply identified the southern Yawuru with their southern neighbours the Karajarri tribe which he defined as patrilineal (it can be noted that Karajarri today do not all recognise patrilineality as the rule). Elkin differentiated the Yawuru (Jauor) from the Jugun (Djugun) people of Broome as part of the Dampier Peninsula tribes whose land ownership, according to him, gave more importance to the place of origin of a person's rayi than from where his or her parents came. ${ }^{25}$ The founder and coordinator of the Jarndu Yawuru women's resource centre, Theresa Barker explains:

Rayi is a spirit-child who walks through the land. And any particular place he go, he has a special location, and this rayi stays there when it's time for a young mother to give birth. The rayi knows when it's time to look for his mother. So say for instance there is a young woman who wants a child and she belongs to the country. So this child walks around and follows this woman and takes this woman for his mother. ${ }^{26}$

23. Personal observation.

24. Chaney (1994).

25. Elkin, A.P., 1927-28, Fieldnotes on Kimberley tribes (unpublished), Australian Institute of Aboriginal and Torres Strait Islander Studies, Canberra. Elkin 1932, pp. 296-333. Elkin 1933, pp. 266-71 and 437-39.

26. Glowczewski ed. 1994, p. 95 (of 1999 version, see note 7). 
For the elders today, rayi spirits are still very important at different levels to determine somebody's totem (jalnga) and place (burru). Contrary to Elkin's statement, women also have their own rayi. Some old and young women still dream today of their rayi or the rayi of their children. People, who grew in a town environment, testify to seeing these 'little people' every time they go to culturally significant places of their country, including the town's beaches, but also some streets and houses. In a situation where there are many marriages with non Aboriginals and where most people live in town far from the other Yawuru sites, or do not dream of rayi, descent is the most common way to claim one's language and country association. The descent through father, mother and all grandparents, the 'blood links' as the local people say, are a different means to determine someone's identity in terms of tribe and place of origin. A man or a woman can have several places, totems and languages inherited from both parents, or through his or her rayi spirit, or in another way. Even if a person does not live in the claimed place or speak the language, he or she can claim one or another according to different situations. In practice, ritual custody of law has also given some rights over the land to in-laws (a father-in-law in the Goollarabooloo claim, a son-in-law in the Yawuru Aboriginal Corporation ). Finally, Aboriginal people of non Yawuru descent but born in the Yawuru region, grown up by Yawuru people and initiated through local law sometimes also consider, and it can be recognised by others, that they have a right to the country. Such a local family for instance is considering claiming a place near a creek north of Broome that was traditionally the northem boundary of the Yawuru with the Ngumbarl, the latter is now almost extinct.

When the native title surveys started, the Yawuru spokesmen preferred to claim links to land through descent from a male or female ancestor, but very rarely in a unilinear, patrilineal or matrilineal way. Contrary to all previous anthropological data on the region, local people recognise a right to land through the mother as well as the father. It is an open question whether this striking contrast between the old assumptions and the current claims is only related to changing patterns of land ownership and kinship or if it is due to an earlier patrilineal bias in anthropology. I tend to suspect that it is a bit of both considering that very little ethnographic work has been done in the early days with these coastal populations, while the promoter of the patrilineal model, RadcliffeBrown, tended to assume that all Aboriginal groups of these regions were patrilineal. We also know, especially since the mid 1970s, that even in groups who, such as the Central Australian Warlpiri, have an open patrilineal ideology, it is compensated by the importance of matrilineal kin and allies, who both have a custody role (kurdungurlu) in relation to the country and the ceremonies of the direct patrilineal kin (kirda). ${ }^{27}$

The remarkable pattern among the Yawuru and the Broome local population is that descent through mother or father is not conceived as unilineal along one gender (mother's mother, mother's mother's mother versus father's father and father's father's father) but as cross-gendered with gender changing every one, two or more generations (father's mother's father or mother's mother's father, etc.). In other terms the system is almost cognatic with exclusion of some relatives along the way, but only if they chose to 'follow the line' of an outsider of another tribe. One might say that with

27. Glowczewski 1989, p. 67 (Plon). Glowczewski 1991a, p. 27; Young 1996, p. 225 (Allen and Unwin and Aboriginal History Inc.). 
such a bilateral logic everybody ends up being related as one entity: such is certainly one level of genealogical understanding when people say that they are 'all one family'. But on the other hand, there is a very strong sense of differentiation between some families and groups. The genealogical survey I undertook for the Jarndu Yawuru Women's Group shows that people locally divide themselves into twelve to fifteen main families with non unilineal descent and people from other groups recognise more or less the same segmentation. The political alliances between these families change all the time despite different mariages which at one level or another have linked each of theses families to all of the others.

\section{Clans, tribes, sections and the production of territorial identity}

The collections of local oral history and the analysis of the early records suggest that traditionally the forming of 'clans', 'tribes', language or local groups and their right to identify with the land or simply use it was stimulated by similar political dynamics and conflicts of interest to those described in the contemporary Yawuru community. One of the reasons we find it so difficult to draw territorial and linguistic boundaries in Australia is, not only because of colonial, social and economical change, but also because the forming of groups was the result of a constant process of recomposition. ${ }^{28}$ This recomposition had at least two reasons: one being the social organisation which relied on kinship to reproduce itself and the other being the Aboriginal perception of land which focuses on places and trails rather then bounded tracts of land.

I have written elsewhere from my desert experience that land was conceived in a topological way as a medium that could expand or be reduced through practice: some places were saturated with the crossing of many trails belonging to different clans or local groups with different dreamings, but also to different tribal and language groups, while other places were like a no-man's land waiting to be identified through eventual imprinting of new events. ${ }^{29}$ The consequence of such a moving landscape is that some places are shared by different groups as meeting places, while others do not have a specific affiliation, but the events connected with these places and the significance they produce can change with generations. It is very clear in the coastal case of the Broome region that some places were shared by two or even more tribal or language groups, for instance the big creek estuaries such as the Willie Creek. Such are the places where the support of different language communities was necessary to bring young men over hundreds of kilometres of ritual journey to be made into culturally responsible men. At the turn of the century, Daisy Bates recorded several of these long journeys and initiation cycles in different gathering places which are all remembered by elders as big 'law' meeting places. ${ }^{30}$

The strategic negotiations undertaken to define the path of initiation for each new initiate was part of the actualisation of the rights to land of the different families and

28. On this flexibility of land boundaries and a critic of previous data, especially N. Tindale's map, see Sutton 1995, pp. 44-46 (Aboriginal History Monograph 3).

29. Glowczewski 1991a, p. 52.

30. Bates, Daisy no date (early 1900s), Native vocabularies-Broome Magisterial District, typescript, Section 12, 2E:16; Social Organisation-genealogies, typescript, Section 3: 2L, 2M, 2N; relationship terms, typescript, Section 3: 5J, I; Native names of places, Section /3E, notebooks 7a, 11b. (Canberra, National Library of Australia). Bates 1985, pp. 163-64. 
language groups involved in the process. Through such rituals the custodian status was reinforced for some, but no one group could have the exclusivity with these places being by definition gathering places. A way to visualise the complex relationship here suggested, would be to conceive of towns located near a state border, in Australia or in Europe, as not belonging to one state but to two states. In the case of some Aboriginal places, it could even be three or more different clan or tribal groups which could share one area. Today families are asked, because of this western bias, to be exclusive in the definition of places for native title purposes. Some do play the game, but they keep reminding us that in the old days they were all 'one family'. And this oneness did not mean confusion but sharing different rights of land use in different circumstances.

Similarly to reproduce social organisation through kinship, alliances needed to be constantly renewed through marriages and other exchange processes, trade of goods or circulation of ceremonies. It is possible that the systems looked unilineal once the descendants of newcomers were associated not so much with a group but to a particular land. But different ways of recognising this connectedness to land must have also been operating. We need here to investigate the principles of land and/or dreaming transmission in relation to the marriage rules and the four sections model the Yawuru practised traditionally. ${ }^{31}$

Garimba man marries Barljarri woman, their children are Burungu

Garimba woman marries Barljarri man, their children are Banaga

Burungu man marries Banaga woman, their children are Barljarri

Burungu woman marries Banaga man, their children are Garimba

We can see that from the perspective of this sections system, the four sections are neither matrilineal nor patrilineal but both: it depends which pair is considered. Two pairs are in a reciprocal father to child relationship, forming two patrimoieties, while the other pairing of sections relates them in a reciprocal mother to child relationship forming two matrimoieties. A third partition of the four sections divides them into what the anthropologists have called the generation, alternate or endogamous moities, represented here by the two pairs of spouses:

two generation moieties: Garimba/Barljarri and Burungu/Banaga

two patrimoieties: Garimba/Burungu and Barljarri/Banaga

two matrimoieties: Garimba/Banaga and Barljarri/Burungu

According to Elkin in the four sections system the two pairs of sections in a father to son relationship (one patrimoiety) were associated to one land; if this is true nothing allows us to deduce that land (and its totem) was handed over from father to son. ${ }^{32}$ In fact, Elkin gave several examples in the Yawuru and Karajarri context of father and son having different totems (and places). He also noted that during the increase rites, even

31. All elders know their section or 'skin' name but most young people do not. It can be understood from the system that in case of a 'wrong' marriage between two people of not appropriate skins or with somebody from a non section system, the section of the child has to be connected to only one of the parent. In fact many Yawuru people acquired their section name through their mother when their father was non Aboriginal. Locally people sometimes call the section name 'tribe'.

32. Elkin 1932, pp. 296-333. 
though both sections of a patrimoiety were present, only the members of one section were the leaders while the members of the other section assisted them.

...my informants stated definitely in a number of cases that the men of a particular section were in charge of the rite, and that they were assisted by the men of the other section of the patrilineal moiety. ${ }^{33}$

This ritual complementarity follows, in fact, the generation moieties' division which in the Yawuru system, contrary to the patrimoities and matrimoities, are named with reciprocal terms: yarradugurjarra and yinimarra. Burungu and Banaga call themselves yarradugurjarra as opposed to yinirra. The two sections of the other moiety, Karimba and Barljarri, also call themselves yarradugurjarra and refer to the first moiety as yinirra. ${ }^{34}$ This suggests that Broome's principle of ritual assistance which follows the generation moiety division, separating the two sections of a patrimoiety, plays the same role as the patrimoiety ritual division into kirda and kurdungurlu of the eight subsections system used by the desert groups. ${ }^{35}$ It is essential to stress the importance of these generation moieties when considering that other western groups who do not have the four sections systems but practise ritual exchanges with the Yawuru people. The western groups also organise some of their rituals according to their own generation moieties. Such is the case of the Bardi coastal people (from Djarindjin and One Arm Point) and all the Western desert people. ${ }^{36}$

Brother and sister normally have the same section name as their mother's mother (and her brother) as well as their father's father (and his sister). In other words, if members of one section, in one area, share the same land and totems, the four sections system is as matrilineal as patrilineal. In fact, mimi, the term for mother's mother can also be used for father's father, while, jamuny, the term for mother's father can be used for father's mother. Similar cross-gender equivalence exist at other levels. Against all anthropological tradition, we should define an 'alternate matrilineal and patrilineal' system, where one inherits from the grandparents (because Ego has the same section as them) and not directly from the parents.

To determine the system of kinship principles ruling land ownership, sections are not enough. We also need to consider marriage rules which can change the apparent reciprocity of the section pairs into a non directly reciprocal chain of alliances between local groups. For instance a rule, reported by the Yawuru, forbids brothers and sisters to both find a spouse in the same group. This means that there is no reciprocal exchange between two groups but an alliance between at least three groups. For instance if the brothers of $A$ marry in $B$, the sisters of $A$ have to marry in $C$, the men of $B$ can marry in $C$ not in $A$. Another rule, expressed by Yawuru informants, forbids a one way alliance between two groups to be repeated at every generation which expands even further the number of groups involved in marriage exchange. Expansion of allies, in and out of the tribal group, necessarily means expansion of possible places of inheritance. Such expan-

33. Elkin 1933, p. 287.

34. Also reported by Daisy Bates in Bates 1985, p. 95. It is important to stress that generation moieties have been underestimated by Radcliffe-Brown for all of Western Australia, who did not understand the importance of Bates data White 1981, pp. 6-27.

35. Glowczewski 1991a, p. 137.

36. Tonkinson 1978 , p. 75 . White 1981 , pp. 6-27. 
sion of allies is present in the old genealogies and prevents the transmission of land from being systematic as the situation varies for different generations of the same group.

This suggests that the individual rayi connection to the land was traditionally critical, allowing the production of personal identities. Local people never seem to emphasise the father over the mother, while grandparents, grand-uncles and grand-aunts on both sides are certainly important. The identification with one or the other of the ancestors varies with personal experience. For instance some of the current ritual custodians are Yawuru though their mother's father or mother's mother's father. The Yawuru language is spoken by only a few people. But Yawuru kinship terms are widely used between members of the whole Aboriginal Broome community (Yawuru and non Yawuru), with many people not necessarily knowing the genealogical links which lead to the use of such or such a term towards a distant relative. Kinship as a learnt behaviour practiced in everyday life is more relevant here then the genealogical knowledge. The transmission of ritual custody over the last generations combined with the crossgendering of the section system leads us to think that non lineal rules always applied to land ownership.

\section{From an oral custody of land to a written title}

The ancestors of Broome families are identified with some specific places by most elders who generally know the place of their respective rayi spirits which can be the same or different from the place where the ancestors grew up. Generally the old people talk about the oldest among them as 'the last true Yawuru' but they identify with their ancestors' country all the descendants of mixed blood, initiated or not, up to five generations younger. Some of those families call themselves 'clans' without a one gender unilineal membership, but all their members are not necessarily aware of their country of origin. Some young people seek such information from the elders but others identify with Broome as a town and do not see a real difference between themselves as Yawuru and other Aboriginal people who grew up in town. Nevertheless the development of new strategies in relation to the Native Title Act 1993 (Cwlth), has led to the separate registration of some of those families into distinct corporations or claiming entities identifying with specific places.

In 1994, the High Court having unanimously confirmed the validity of the Commonwealth Native Title Act 1993, a claim made by the Kimberley Land Council on behalf of the Yawuru Aboriginal Corporation to the shores and sea from Cape Villaret to the north of the Broome was accepted as valid by the Native Title Tribunal. Goollarabooloo lodged its own claim over the town. Considering that full or unqualified beneficial ownership would be difficult to prove if there were opposing claims to the same land and if each of the applicants could not prove that they had exclusive possession, the Kimberley Land Council advised the Yawuru Aboriginal Corporation and Goollarabooloo, and also a more recent dissident group which called itself 'Djugan' that their chances were better if they united. In response they formed the Rubibi working group. The cover page of the first Rubibi newsletter, June 1995, produced by the Kimberley Land Council states:

These three groups met over several days to discuss Native Title rights and interests in the Broome region and to see if they could agree on how they should approach 
Native Title claims. At the end of the meeting it was agreed by everyone that each of the three groups was made of people and families who have Native Title rights in the Broome region. It was agreed that the best way to deal with Native Title claims in the region was for the three groups to come together as one group and to speak with 'one voice' on all issues concerning both Native Title and Aboriginal Heritage. It was decided that the name for this new group should be Rubibi which refers to an important water place near Kennedy Hill and was a name traditionally used to refer to the Broome area. ${ }^{37}$

The Rubibi working group planned to become a prescribed body corporate, that is a legal entity under the new Native Title Act 1993 (Cwlth) established to hold the title on behalf of all the land holding groups. A Kimberley Land Council lawyer started to work on a constitution which would reflect the community's needs. When the first proposal was discussed in 1995 in a public meeting, interestingly, the names of the three groups-Yawuru, Djugan and Goollarabooloo-were not mentioned but instead a definition of membership was proposed which included all native title holders for the country between Willie Creek and Gourdon Bay.

The definition of a native title holder opened many family discussions. Is there a right to land for Aboriginal people who can prove a continuity of use and occupation of the land through economical or religious connections but who are of non-Yawuru or non-Jugun descent? Some people say that the right to use the land is not the same as having a title to the land. Others would like to give a right to the land to the 'historical people' whose parents were brought to the region as children. But the situation seems different from the Hopevale case in Queensland, as the majority of the people in Broome do recognise the Jugun and Yawuru descendants as the traditional owners. In fact some of the non-Jugun and non-Yawuru families who have 99 year leases through the Western Australian Aboriginal Land Trust have been worried that the native title process might question their right to their lease. In meetings, organised on one side by the Rubibi Working Group to discuss the proposed constitution and on the other by the Aboriginal Land Trust to review the way the Trust operates, these conflicting interests have been demonstrated but the rights of the lessees and the native title of the traditional owners were not questioned.

When the Rubibi Working Group was set up, the challenge was to form a future Rubibi Council which would represent all the families who have a right to land in Broome and Roebuck Plains down to Barn Hill. Over the years many families felt that they were not consulted adequately or that they might be excluded from the membership. People feared that once native title was recognised in the Broome area, the Council's executive might monopolise the decisions about land use instead of giving a share to all the families concerned. If the Rubibi Council was to be given native title for all the Yawuru country, any family request of land would have to be addressed to the Council. But then how would the Council decide the allocation of land to hundreds of entitled claimants?

37. The word rubibi according to some locals is an Aboriginal pronunciation of Roebuck Bay. It is denied by others: maybe Roebuck Bay termwas chosen because it was close to the Indigenous Rubibi? 
Some years ago, a few Aboriginal families of Yawuru or non-Yawuru descent were given leases on blocks of reserve land outside of town. Some are inhabited by extended families, others by smaller family groups, or stay abandoned because the lessee cannot afford to build. Other families who are recognised as having a right to the land were not given anything and often live in overcrowded Homeswest houses but are still hoping for a block of land. Since the Native Title Act 1993 (Cwlth) was passed the Western Australian Aboriginal Land Trust has stopped granting leases to Aboriginal people in Broome. The reason given being that the Trust cannot afford to service the blocks with water and electricity. Some of the lessees already have difficulties with water and complain that the shire is not building a water reservoir on the reserve land or grading the roads. Another problem is that banks are unwilling to lend on the security of a 99 year lease. Collaboration between the shire and also Homeswest and the Western Australian Water Authority could be part of a regional agreement. Any unfairness could be remedied with new arrangements on native title land or in a local regional agreement. However the allocation of private blocks will be in competition with commercial ventures. If Aboriginal interest is linked with the town's development not just as a compensation for land but as direct Aboriginal involvement in the ventures and the promotion of Aboriginal culture, the Rubibi Council might become a model of a town-based Aboriginal self determination.

\section{Towards local and regional agreements}

The first task of the Rubibi Working Group in 1995 was to negotiate the use of a tract of land at the entrance to Broome where a local pearling and fishing company wanted to build a shopping centre. The developer, Paspaley Pearls ${ }^{38}$, recognised the effect of the Native Title Act 1993 (Cwlth) and offered compensation for the use of the Yawuru site. The company also promised to build a language centre. Once the agreement was signed, $\$ 150,000$ was placed in a trust account for Rubibi. Many Aboriginal and nonAboriginal inhabitants of Broome were happy as after the crocodile farm dispute it seemed that the reconciliation process was on its way. The Broome Shire entered an informal agreement to consult with Rubibi on any development proposal. Soon after some of the shire councillors and local lobbyists expressed their resistance to this move. On the Aboriginal side, discontent could also be heard as no language centre was built and the money was creating some jealousy. In fact the Paspaley compensation could not be used until Rubibi was incorporated with a constitution accepted by all its members. Many families were pressing for a place to be built for the elders on the sea shore near the law ground, Garnin. Meantime three of the elders passed away, the bitterness grew, and a local family, incorporated as the Leregon clan, put its own claim on this tract of land.

A new process had nevertheless been initiated. The Rubibi working group had meetings several times a week to consider the numerous development proposals, from sixty in 1995 to more since (tourist resorts and businesses, aquaculture, sand mining, housing, marina, etc.). It was believed that some benefit could be gained for Aboriginal

38. Paspaley Pearls was funded by a Greek immigrant who had the idea to adapt culture pearl to the Broome waters. The company is now run by his son and has real estate and other businesses in Broome, Darwin and overseas. 
people in the long run if development plans take into account Aboriginal priorities. In an attempt to facilitate that process, the Kimberley Land Council arranged for a team of academics and practitioners from the Royal Melbourne Institute of Technology to sit with the Rubibi group to draft a study plan as part of their research. Their report presents many interesting ideas and recommends among other things the establishment of a Broome Aboriginal cultural centre, a coastal park with 'cultural places' and a joint Rubibi-Shire Strategic Planning group. ${ }^{39}$ Since then development has been discussed case by case. According to the 1995 first issue of the Kimberley Land Council news:

the pressure could be taken off people if a negotiated settlement was reached through a local regional agreement...This agreement would mean that Native Title holders would approve the development for certain areas of land, in return for a number of other benefits such as a joint management of parks, fishing and hunting rights, financial compensation for loss of land and participation in the decision making process about what happens in the area.

Such an initiative is believed to be at the heart of greater regional autonomy. Discussions for a Kimberley-wide regional agreement or for setting up a Regional Authority are still at a working stage between the Coalition of Kimberley Aboriginal Organisations and the Aboriginal and Torres Straight Islander Commission. The long term hope is that a direct funding and service delivery arrangement with the Commonwealth will replace the current bureaucratic system which prevents real self-management. It has to be acknowledged that on a smaller scale, Rubibi has shown the way of how a local agreement could be undertaken. Sue Jackson, a geographer who has a long experience of the region and participated in the Royal Melbourne Institute of Technology survey, has discussed extensively the Rubibi Working Group mediation process with the Broome Shire. Jackson stressed the inequality of power in structure, numbers and funding opposing the two parties. But she also insisted on the dedication of the Rubibi members involved who give their time and ideas benevolently in numerous meetings with the hope of a better future for their town and country. ${ }^{40}$ Many are now directly involved in a Town Planning Framework.

Many meetings took place to draft a constitution proposal. After three years in mid-1998 an application was lodged with the Registrar for the creation of a corporate body, the Rubibi Aboriginal Land, Heritage and Development Council (Aboriginal Corporation) The main changes in relation to the first draft involved the structure of the Council and its modes of representation. After registering over 11 claims with the Native Title Tribunal, the Rubibi Working Group had 39 registered claimants who could act as the representative members. But the community felt that this list of claimants was not sufficient to defend the various interests of some of the 2,000 people represented by the Rubibi claims. In 1997 some registered claimants, dissatisfied with the constitution proposal, announced their decision to leave Rubibi. This lack of consensus in relation to the constitution was threatening the whole process of claims and agreements. If Rubibi could not provide a constitution including all the registered claimants, the registered claims would become invalid. Several general meetings were called in 1998 and it was decided that instead of an elected committee with a consultative body of nominated

39. Royal Melbourne Institute of Technology 1995, p. 40 .

40. Jackson 1996, pp. 32-3. 
elders as originally proposed, there should be a General Assembly with four members (and two proxies) from each of the family group identified, plus different subcommittees to work on different issues.

The proposed constitution stated the following objectives: maintaining Aboriginal law, language and culture, and assuring the protection of the traditional country; promoting respect for Aboriginal law within the Broome region; relieving the dispossession, lack of educational opportunities, poverty, ill-health and suffering of the Rubibi Community by different means including the contribution to the cultural, social and economic development of the Rubibi Community; entering into land use agreements; taking and defending legal proceedings affecting native title rights and interests; receiving any grant, settlement, compensation, payment or other consideration, and contributing the same to either the Rubibi Aboriginal Charitable Trust or to its Charitable Objects; and performing the role and carry out the functions of a Registered Native Title Body Corporate and a Prescribed Body.

\section{Update}

In July 1999, the Rubibi Aboriginal Land, Heritage and Development Council was still waiting for its incorporation under the Aboriginal Councils and Associations Act 1976 (Cwlth). Some members who had left Rubibi came back while others resigned, being unsatisfied with the way their interests were represented. Despite this turmoil a decision group with several non Aboriginal staff members stayed involved in mediation processes, looking at propositions of joint ventures and promoting the construction of a regional Aboriginal cultural centre. ${ }^{41}$ The main reason for Rubibi's instability and the constant conflict of interest between the families partly lies in the fact that some incorporated groups and individuals do not accept the maintenance in the Constitution of a Council of Elders which excludes many old people on the basis that they did not maintain a 'traditional' life. Considering the history of the region, tradition has been transmitted in many different ways: through ritual activities and language for only a few but knowledge of country and economic survival for the majority. Consequently the ritual elders who are a handful today are not the only leaders in the community. Contrary to a traditional Aboriginal power structure where the elders regrouped all the older generation, the current Rubibi Council model seems to privilege some people against others, excluding families who already suffered dispossession and denying self-determination to younger people who have the skills to bridge two worlds. The question is how to reconcile a traditional model with a western corporation structure where all descendants claim a right to have a voice.

The historical background, the socio-cultural foundations and the local strategies that have led a dispossessed urban population which has descended from traditional Aboriginal groups, European and Asian migrants, to reconstruct their local past has been discussed here. Creating a new form of 'oneness', the Rubibi entity is facing the

41. The Aboriginal Culture Centre working party involving many members of the Broome community and representatives from other communities of the Dampier Peninsula has conducted a wide scale survey on the needs of the region in terms of cultural maintenance, young peoples' training and creative incentive, but also economically sustainable ways to promote culture and protect the land. Glowczewski ed., pp. 1-59. 
thallenge today of respecting different local family identities and redefining its leadership structure while working towards a Broome development process aiming at reconciling the local Aboriginal community with the constantly growing non Aboriginal population. The conflict is currently tearing apart the whole community, but as some locals wisely say: 'you know us mob we hit first and then we talk'. ${ }^{42}$

\section{Acknowledgment}

This paper results from a research on Perception of identity and alterity in the Kimberley land-claims and Identity process and conflicts on the north-west coast conducted in Broome between 1992 and 1998, as a researcher in anthropology employed by the French Centre National de la Recherche Scientifique (CNRS). I am grateful to all the Jugun, Yawuru and other local Aboriginal people who taught me about their country, and especially some elders now gone, Joe Bernard, Matthew Gilbert, Jack Edgar, Tommy Edgar, Gladys Gregory. My debt goes to those who introduced me to the Broome community, my husband, Wayne Barker, and the founders of the Jarndu Yawuru Women's Group, Theresa Barker, Pat Torres, Doris Edgar, Cissy Djiagween, Margaret Robinson, Mary Manolis, and other strong women who shared with me their genealogical knowledge, Elsie Edgar, Selma Saddler, Alberta McKenna, Mary MacKenzie, Mary Tarran, MaryLourdes Farrell, Joyce Fong, Clara Roe Jakamarra, Daisy Kitaura, Eddie Saaban. Many thanks to Patrick Sullivan, senior anthropologist working for the Kimberley Land Council, who provided helpful comments on an earlier draft of this paper presented at the Australian Anthropological Society conference in 1995.

\section{References}

Ackerman, Kim 1995, 'Kimberley and Dampier Land' in Country-Aboriginal Boundaries and Land Ownership in Australia, ed. P. Sutton, Canberra, 1995, p. 99.

Bates, Daisy 1938, The Passing of Aborigines. London, 1938.

Bates, Daisy 1985, The Native Tribes of Western Australia, ed. I White, Canberra, 1985.

Bishofs, P 1908, 'Die Niol-Niol, ein eingeborenenstamm in Nordwest-Australien', Anthropos, bd. 3, 32-40.

Bradshaw, Elisabeth and Fry, Rachel 1989, A Management Report for the Lurujarri Heritage Trail, Broome, Western Australia, Perth.

Chaney, F.M. 1994, The Particular Significance to Aboriginals of Land Near Broome to Be Leased for the Purpose of a Crocodile Farm. Report to the Minister for Aboriginal Affairs under s. 10(4) of the Aboriginal and Torres Strait Islander Heritage Protection Act 1984, Canberra.

42. The Jarndu Yawuru Oral History project that I helped to put together (Glowczewski ed. 1994) was accepted in 1994 by the Aboriginal publisher, Magabala Books, who received a grant from the Australia Foundation for Culture and the Humanities to publish it: a reduced version of the original manuscript went to the printer in June 1999 but its publication is temporarily withheld for Native Title reasons. The families of 4 of the 15 storytellers involved were avised to keep their contribution for the Court. Considering the strength of the storytellers' testimonies as a proof of the cultural attachment with the land of many different families of Broome, I am not convinced that delaying publication is serving the purpose of the land claim, unless the strategy is to favor some against others. Unfortunately it is Broome politics. 
Elkin, A.P. 1932, 'Social organization in the Kimberley division, North-Western Australia', Oceania, vol. 2, no. 3, pp. 296-333.

- 1933, 'Totemism in North-Western Australia (The Kimberley division)', Oceania, vol. 3, no. 3, pp. 257-296, no. 4, pp. 435-481.

Glowczewski, B. 1983, 'Manifestations symboliques d'une transition économique: Le 'Juluru' culte intertribal du 'cargo' en Australie centrale et occidentale', L'Homme, vol. 23, no. 2, pp. 7-35.

— 1991a, Du Rêve à la Loi Chez les Aborigènes-Mythes, Rites et Organisation Sociale en Australie, Paris.

- 1991b,Yapa-Peintres Aborigenes de Balgo et Lajamanu, Paris. ed. 1996, Language and Culture Survey in the Kullari Region, conducted by Wayne Barker, Quentin Bruce, Mary-Lou Farrell, Veronica Francis, Barbara Glowczewski, Brian Lee, Mary Manolis, Veronica McKeon, Mary Tarran for the Aboriginal Arts and Culture Centre Working Party, Broome, Western Australia.

_ 1998a, 'All one but different': Aboriginality: national identity versus local diversification in Australia' in Pacific Answers to Western Hegemony, ed. J. Wassmann, Oxford, pp. 335-54,

_ 1998b, 'Le corps entre deux vents: à propos du mythe "Two-Men" dans le nordouest australien' in La Production du Corps, ed. M. Godelier \& M. Panoff, Amsterdam.

—_ ed. 1999, Liyan-A Living Culture: Jarndu Yawuru Oral History Project, (ed.). Broome, Western Australia.

Hawke, Steven and Gallagher, Michael 1989, Noonkanbah-Whose Land, Whose Law, Fremantle, Western Australia.

Hosokawa, K. 1991, The Yawuru Language of West Kimberley, PhD thesis, The Australian National University, Canberra.

Jackson, S. 1996, When History Meets the New Native Title Era at the Negociating Table-A Discussion Paper, Darwin.

McGregor, W.B. 1988, Handbook of Kimberley Languages, vol. 1, General Information., Canberra.

Moyle, A. 1981, Songs from the Kimberley, Canberra. (Companion booklet for a 12-inch LP disc, Cat. no. AIAS/13 (also audio tape) recorded in 1968).

Radcliffe-Brown, A.R. 1930-1931, 'The social organisation of Australian tribes', Oceania, vol. 1, no. 1, pp. 34-63; no. 2, pp. 206-46; no. 3, pp. 322-41; no. 4, pp. 426-56.

Roe, Paddy and Muecke, Stephen (eds) 1983, Gularabulu, Fremantle, Western Australia.

Royal Melbourne Institute of Technology 1995, Keeping country-A Draft Report Submitted to the Rubibi Working Group, Melbourne.

Sullivan, Patrick 1995, Beyond Native Title: Multiple Land Use Agreements and Aboriginal Governance in the Kimberley, Canberra.

Sutton, Peter 1995, Country-Aboriginal Boundaries and Land Ownership in Australia, Canberra.

Tarran, John and Djiagween-Tarran, Mary, Submission to Broome Planning TaskforceRepresenting the Interests of the Local Aboriginal Community in Broome in 
Development Plans, with Particular Emphasis on Plans for Development in the Minyirr Area, Broome, Western Australia.

Tindale, N. 1974, Aboriginal Tribes of Western Australia, Canberra.

Tonkinson, R. 1978, The Mardudjarra, Living the Dream in Australia's Desert, New York.

Worms, E. 1940, Religiose Vorstellungen und Kultur einiger Nord-westaustralischen Stämme in fünfzig Legenden, Annali Lateranensi vol. 4, pp. 213-82.

Worms, E. 1944, 'Aboriginal place names in Kimberley, Western Australia', Oceania, vol.14, no. 4, pp. 284-310.

White, Isabel 1981, 'Generation moieties in Australia: structural social and ritual implications', Oceania, vol. 52, pp 6-27.

Young, Elspeth 1996, 'Resettlement and caring for the country: the Anmatyerre experience' in Chapman, V. and Read, P., Terrible Hard Biscuits-A Reader in Aboriginal History, St Leonards, New South Wales. 